\title{
DeVElopMent OF POGIL BASEd CALCulus Module For INFORMATICS ENGINEERING STUDENTS
}

\author{
Weni Gurita Aedi ${ }^{1)}$, Lisda Fitriana Masitoh ${ }^{2)}$ \\ ${ }^{1)}$ Universitas Pamulang, Tangerang Selatan, Banten, Indonesia \\ E-mail:dosen01906@unpam.ac.id \\ ${ }^{2)}$ Universitas Pamulang, Tangerang Selatan, Banten, Indonesia \\ E-mail:dosen01928@unpam.ac.id
}

\begin{abstract}
The purpose of this study was to develop a calculus learning module based on POGIL for Informatics Engineering students. The POGIL-based module contains namely exploring, discovering, and applying. Through POGIL, students are more responsible for their educational assignments, learn to rely on their ability to think rather than just remember and develop positive relationships with other students. The module was developed and contains the POGIL syntax. The quality of development results is determined based on Nieveen's criteria, namely valid, practical, and effective. This is a Research and Development Study that applies the Plomp Model which consists of the initial research, development, and assessment phases. The subjects of this research were students of Informatics Engineering at the University of Pamulang. The research instruments used were validation sheets, student assessment questionnaires, and calculus questions. In terms of validity, based on the assessment conducted by experts, has met the valid criteria with a very good category with an empirical score that is 312. In terms of practicality, based on the results of student assessments after participating in learning using the developed tools, it is in the very good category with an empirical score of 1924. In terms of effectiveness, the result is $Z=1.75>Z_{-}$a $=1.645$, so Ho is rejected, which means that the proportion of students who score 70 is more than $74.99 \%$. The results showed that the calculus learning module met the criteria of validity, practicality, and effectiveness.
\end{abstract}

Keywords: Calculus Module; POGIL; Research and Development

\section{INTRODUCTION}

Calculus is the science of change, as geometry is the science of form and algebraic knowledge of working to solve equations and their application (Mutakin, 2013: 52). Calculus has wide applications in the fields of science, economics, and engineering. Calculus, both calculus I and calculus II, is a subject that must be taken by students of Informatics Engineering. It can also be said that calculus is a prerequisite course for other courses. Accordingly, students must realize that calculus is an essential subject and requires a high level of reasoning in understanding it. However, the fact shows that calculus courses are less preferred by Informatics Engineering students because they contain complex calculations which are even considered to hinder study time or reduce the students' grade point average (GPA). The students still have difficulty taking calculus lessons. Additionally, the current modules do not encourage students to be active and independent in learning. Besides, the average calculus score of informatics engineering students is below 70. In line with this, the research conducted by Mutakin (2013: 59) also concluded that there are two factors causing student difficulties, namely interest learning and low basic calculus skills.

To make Informatics Engineering students more active in learning calculus, quality learning resources were accordingly developed. One of the learning resources that can be developed is a module. The module contains learning material, a set of commands, or questions that are used to find or explore a concept. The use of modules in calculus learning activities can help direct students to find concepts independently or collectively that can facilitate students so that they can learn actively and creatively. One approach that can create interesting learning is POGIL (Process Oriented Guided Inquiry Learning). According to the results of research conducted (Malik et al., 2017) showed that POGIL can improve students' thinking skills. By developing a 
calculus learning module based on POGIL, it can facilitate the Informatics Engineering students to learn actively.

The POGIL-based module contains three parts, namely exploring, discovering, and applying. The unique characteristic of POGIL is the use of a learning cycle to conduct inquiries and focus on the skills development process through the use of team assignments (Geiger, 2010: 20). Through POGIL, students are more responsible for their educational assignments, learn to rely on their ability to think rather than just remember, improve performance skills on the subject matter, and develop positive relationships with other students. In the POGIL class students work together in study groups to gain knowledge and develop understanding through guided discovery by examining data, models, or examples.

The objectives of POGIL are: (1) to develop mastery of the material by means of students constructing something through understanding; (2) to develop and improve important skills such as information processing, oral and written communication, critical thinking, problem-solving, metacognition, and assessment (Moog \& Spencer, 2008: 3) a similar opinion was expressed by Hanson (2006: 5) that in POGIL students work in study groups to carry out special activities to improve content mastery and develop process skills in learning, thinking, problem-solving, communication, teamwork, management, and assessment.

Research by Malik et al. (2017) showed the average result of all teacher activity meetings is $88.88 \%$ and student activity is $87.04 \%$ which is in the very good category. Besides, there was an increase in students' critical thinking skills by 0.61 which was included in the moderate category. Thus, the POGIL learning model can be used as an alternative to improving students' critical thinking skills. Furthermore, the research conducted by Oktafiyah, Ibnu, and Fajaroh (2018) showed that there are differences in cognitive learning outcomes of students who are taught with POGIL. By using POGIL can improve student cognitive learning outcomes. While in this study POGIL was implemented in calculus learning. If in previous research POGIL can improve thinking skills and can improve cognitive learning outcomes, in this study POGIL implemented to improve calculus learning outcomes.

The research was carried out because there were informatics engineering students who found it difficult to learn calculus. To create a fun and meaningful calculus lesson, one of them uses the POGIL approach. So that the purpose of this study is to develop a calculus learning module for informatics engineering students. The developed calculus learning module contains the POGIL syntax.

\section{MethodOLOGY}

\section{A. Research Procedure}

This research is research and development. The development model used in this research is the Plomp development model which consists of three stages, namely the preliminary research phase, the development or prototyping phase, and the assessment phase (Plomp, 2013: 19).
First, the initial research phase. This phase aims to gather information about problems that occur in the field. In this phase, identification and study of the student's condition, ongoing calculus learning, and the results of calculus learning of the Informatics Engineering students at Pamulang University were carried out.

Second, the development phase. In this phase, the activity of compiling modules from this phase is draft 1 of the calculus learning module based on POGIL. Then in this phase, a formative assessment is also carried out by experts that aim to find out whether the draft 1 calculus learning module that has been compiled is valid or not based on the expert's assessment. If the results of the analysis of the experts 'assessment of draft 1 are without revisions or minor revisions, then it is followed by a trial of draft 1 . However, if the results of the analysis of the experts' assessment of draft 1 need revision, a revision is made so that draft 2 . Draft 2 also requires an assessment of the experts. expert. If the results of the analysis of the experts 'assessment of draft 2 are without revisions or minor revisions, then it is followed by a trial of draft 2 . However, if the results of the analysis of the experts' assessment of draft 2 need revision, then a revision is made so that it gets draft 3 , and so on so that a cycle occurs. The cycle will stop if the results of the expert assessment analysis are not revised. This means that a valid calculus learning module has been obtained.

Third, the assessment phase. In this phase, a valid calculus learning module is tested based on expert judgment to find out whether practically the compiled calculus learning module can be applied in class and whether the valid calculus learning module has achieved the results according to the stated objectives. Through this trial activity, summative assessment is carried out to test the practicality and effectiveness of the developed calculus learning module.

\section{B. Trial Design}

The trials in this study include trial I and trial II. Trial I was carried out limited to a few students, while trial II was conducted on one class. The trial aims to obtain responses from students as consideration for improving the learning module before it is implemented in classroom learning. Modules are given to students to read and understand. After that students are asked to provide a module assessment by filling out the student assessment sheet for the calculus learning module. In addition to giving a checkmark $(\sqrt{ })$ on the answer choices, filling out the student assessment sheet for the student worksheets also in the form of providing comments/suggestions for improvement as consideration for improving the worksheets. In the second trial, the calculus learning module was implemented in classroom learning. Trial II aims to determine the practicality of student assessments. Meanwhile, the effectiveness of the calculus learning module is seen from the results of the calculus learning achievement test.

\section{Test Subjects}

The first trial subjects in this development research were nine informatics engineering students in class 02TPLP005 
Pamulang University. These students consist of three highability students, three medium-ability students, and three low-ability students based on learning outcomes in Calculus I. Meanwhile, the second trial subject involved all students of class 02TPLP004 Pamulang University.

\section{Techniques and Instrumen of Data Collection}

Data collection techniques in this study were carried out in several ways, namely providing validation sheets, student assessment questionnaires, and calculus questions. The instrument to determine the validity consisted of a module validation sheet and a calculus test instrument validation sheet. The instrument to determine practicality consists of student assessment sheets. The instrument to determine the effectiveness consisted of a calculus learning achievement test.

\section{E. Data Analysis Techniques}

The data analysis techniques used in this study were (1) qualitative data in the form of comments and suggestions were analyzed qualitatively, then used as input to revise the product being developed. (2) Quantitative data with a scale of five are converted into qualitative data, concerning the formula adapted from Azwar (1998: 163) in Table I.

TABLE I

DATA CONVERSION CRITERIA

\begin{tabular}{cc}
\hline Interval Score & Criteria \\
\hline$X>\overline{\mathrm{x}}+1,5 \mathrm{SB}_{\mathrm{x}}$ & Very Good \\
$\overline{\mathrm{x}}+0,5 \mathrm{SB}_{\mathrm{x}}<X \leq \overline{\mathrm{x}}+1,5 \mathrm{SB}_{\mathrm{x}}$ & Good \\
$\overline{\mathrm{x}}-0,5 \mathrm{SB}_{\mathrm{x}}<X_{\leq} \overline{\mathrm{x}}+0,5 \mathrm{SB}_{\mathrm{x}}$ & Pretty Good \\
$\overline{\mathrm{x}}-1,5 \mathrm{SB}_{\mathrm{x}}<\bar{X} \leq \overline{\mathrm{x}}-0,5 \mathrm{SB}_{\mathrm{x}}$ & Not So Good \\
$X \leq \overline{\mathrm{x}}-1,5 \mathrm{SB}_{\mathrm{x}}$ & Not Good \\
\hline
\end{tabular}

Information:

$X \quad=$ Respondence Score

$\bar{x}=$ Ideal average

$\mathrm{SBX}=$ Ideal standard deviation

where:

$\bar{x}=\frac{1}{2} \mathrm{x}$ (maximum ideal score + minimum ideal score $)$

$\mathrm{SBx}=\frac{1}{6} \mathrm{x}$ (maximum ideal score - minimum ideal score $)$

The developed calculus learning module is said to be valid if the results of the expert's assessment get a minimum good category. The developed calculus learning module is said to be practical if the results of student assessments get at least good categories. The calculus learning module developed is said to be effective if at least $75 \%$ of the proportion of students has reached a score of 70 .

Analysis of the effectiveness of learning devices, using the $\mathrm{Z}$ proportion test. With the test statistics used according to Walpole (1995: 320) that can be seen in question (1) and (2).

$$
Z=\frac{x-n p_{0}}{\sqrt{n p_{0} q_{0}}}
$$

where

Information:

$$
q_{0}=1-p_{0}
$$

$x=$ the number of students who reached the set criteria

$p_{0}=$ the proportion of samples that were hypothesized

$n$ = many students

\section{RESULTS AND DISCUSSION}

The development of the calculus learning module in this study has been carried out through the Plomp stage. Through these stages, researchers can find out the quality of the learning modules being developed. According to Nieveen (1999: 126), quality development products meet the criteria of validity, practicality, and effectiveness. Therefore, based on the results of expert validation and field trials, it is known that the learning module developed has met the criteria of being valid, practical, and effective.

In terms of validity, based on the assessment conducted by experts, the final product of the POGIL-based calculus learning module has met the valid criteria with a very good category with an empirical score for LKS that is 312 from a score range of 78 - 390. The data description shows that based on expert validation, the calculus learning module the resulting product is suitable for use. This learning tool is valid because in its development it has been based on relevant theories. Even though it has been declared valid in the very good category, there are still some aspects that are only in the good or good enough category.

In terms of practicality, based on the results of student assessments after participating in learning using the developed tools, it is in the very good category so that it is declared practical with an empirical score of 1924 from a score range of $420-2100$. The data description shows that the learning module produced by the POGIL approach can be implemented well. This achievement is because researchers have anticipated that after implementing POGIL in the calculus learning process in the classroom, researchers as lecturers of calculus courses as executors carry out reflection activities to find out the deficiencies that occur during the calculus learning process on that day. If there is a shortage on that day, efforts are made to improve the learning process at the next meeting. Lecturers in calculus courses provide extra direction and guidance to each group in finding certain mathematical facts, concepts, principles, or procedures so that students do not have difficulty facing or adapting to a different learning environment than usual. So that it can make calculus learning more fun.

In terms of effectiveness, using $\alpha=0.05$, the results of the calculation of the $Z$ value of the calculus test results data. The $Z$ value of the calculus achievement test result data shows that the result is $Z=1.75>Z_{-} \mathrm{a}=1.645$, so Ho is rejected, which means that the proportion of students who score 70 is more than $74.99 \%$. Accordingly, it can be concluded that the development of the POGIL-based 
calculus learning module that was developed meets the criteria for being effective.

So that the developed calculus learning module can be said to be valid, practical, and effective. In line with this, the research conducted by Purnomo and Abadi (2016) also showed valid, practical, and effective results. Purnomo and Abadi's research also develops POGIL-based learning tools. Where learning with POGIL can improve student mathematics learning outcomes. (Purnomo \& Abadi, 2016).

This is due to the calculus learning steps designed to accustom students to always carry out activities following the POGIL approach. The data description shows that the resulting module can be used as an alternative to supporting learning modules to improve the learning achievement of calculus in informatics engineering students.

\section{CONCLUSIONS}

First, the developed calculus learning module meets the valid criteria with a very good category with an empirical score for LKS that is 312 from a score range of $78-390$.

Second, the developed calculus learning module fulfills the practical criteria in a very good category based on the results of student assessments with an empirical score of 1924 from a score range of $420-2100$.

Third, the developed calculus learning module fulfills the effective criteria in terms of learning achievement. The result is $Z=1.75>Z \_\mathrm{a}=1.645$, so Ho is rejected, which means that the proportion of students who score 70 is more than $74.99 \%$.

\section{REFERENCES}

Azwar, S. (1998). Tes prestasi fungsi pengembangan pengukuran prestasi belajar. Yogyakarta: Pustaka Belajar.

Geiger, M.P. (2010). Implementing POGIL in allied health chemistry courses: insights from process education. International Journal of Process Education, 2, 1933.

Hanson, D.M. (2006). Instructor's guide to process-oriented guided-inquiry learning. Stony Brook, NY: Stony Brook University.
Malik, A., Oktaviani, V., Handayani, W., \& Chusni, M. M. (2017). Penerapan Model Process Oriented Guided Inquiry Learning (POGIL) untuk Meningkatkan Keterampilan Berpikir Kritis Peserta Didik. Jurnal Penelitian \& Pengembangan Pendidikan Fisika, 3(2), $127-136$.

Moog, R.S. \& Spencer, J.N. (2008). POGIL: An overview. Dalam Moog, R.S. \& Spencer, J.N. (Eds.), ACC symposium series 994 process-oriented guided inquiry learning (POGIL). (pp. 1-13). Washington, DC: American Chemical Society.

Mutakin, T.Z. (2013). Analisis Kesulitan Belajar Kalkulus I Mahasiswa Teknik Informatika. Jurnal formatif 3(1): 49-60 ISSN: 2088-351X.

Nieveen (Eds). (1999). Educational design research part A: an introduction (pp.10-51). Enschede: SLO.

Oktafiyah, N.L., Ibnu, S., \& Fajaroh, F. (2018). Pengaruh Pogil dan Verifikasi serta Kemampuan Awal Terhadap Hasil Belajar Kognitif dan Keterampilan Proses Sains Siswa. EduChemia: Jurnal Kimia dan Pendidikan 3(1) 14-28.

Plomp, T. (2013). Educational design research: an introduction. Dalam T. Plomp \& N. Nieveen (Eds), Educational design research part $A$ : an introduction (pp.10-51). Enschede: SLO.

Purnomo, M.E. \& Abadi, A.G. (2016). Developing Mathematics Instructional Package with POGIL that is Oriented to The Competences in Curriculum 2013. Proceeding of $3^{\text {rd }}$ International Conference on Research, Implementation and Education of Mathematics and Science Yogyakarta 162-172.

Straumanis, A. (2010). Classroom implementation of process oriented guided inquiry learning $A$ practical guide for instructors. Charleston, SC: College of Charleston.

Walpole., \& Ronald E. (1995), Pengantar Statistika. Jakarta : PT Gramedia Pustaka Utama. 